\title{
A method to assess safety and resilience in radiopharmaceuticals production process
}

\author{
Cláudio H. S. Grecco ${ }^{a^{*}}$, Mario C. R. Vidal ${ }^{\text {, Isaac J. A. L. Santos }}{ }^{\mathrm{c}}$ and Paulo V. R. Carvalho ${ }^{\mathrm{d}}$ \\ ${ }_{a, c, d}$ Instituto de Engenharia Nuclear (IEN - CNEN/RJ),Divisão de Instrumentação e Confiabilidade Humana \\ Rua Hélio de Almeida, 75, Cidade Universitária - Ilha do Fundão, 21941-906 Rio de Janeiro, \\ agrecco@ien.gov.br,'luquetti@ien.gov.br, ${ }^{d}$ paulov@ien.gov.br \\ ${ }^{b}$ Programa de Engenharia de Produção (PEP - COPPE/UFRJ), Grupo de Ergonomia e Novas Tecnologias \\ (GENTE), Av.Horácio Macedo, 2030 - Bloco G - Sala G 207 - Prédio do Centro de Tecnologia, Cidade \\ Universitária - Ilha do Fundão, 21941-914 Rio de Janeiro, RJ, mvidal@ergonomia.ufrj.br
}

\begin{abstract}
Radiopharmaceuticals are radiation-emitting substances used in medicine for radiotherapy and imaging diagnosis. A Research Institute, located in Rio de Janeiro, produces three radiopharmaceuticals: the sodium iodate is used in the diagnosis of thyroid dysfunctions, the meta-iodo-benzylguanidine is used in the diagnosis of cardiac diseases, and the fluordesoxyglucose is used in diagnosis in cardiology, oncology, neurology and neuropsychiatry. This paper presents a method to access safety and resilience in radiopharmaceuticals production processes. The method uses resilience indicators in order to proactively evaluate and manage the safety.
\end{abstract}

Keywords: ergonomics, resilience, indicators, performance, accidents

\section{Introduction}

Contemporary view on safety emphasizes that safety critical organizations should be able to proactively evaluate and manage safety of their activities. This proactivity should be endorsed in the organizational safety management. Safety, however, is a phenomenon that is hard to describe measure, confirm, and manage. Technical reliability is affected by the performance of the employees. Furthermore, the effect of the management actions, working conditions and the culture of the organization can not be ignored when evaluating the overall safety of the activities.

Scientists in the field of safety critical organizations state that safety emerges when an organization is willing and capable of working according to the demands of their task, and when they understand the changing vulnerabilities of their work [1][2][3][4]. Adopting this point of view we state that managing the organization and its sociotechnical phenomena is the essence of management of safety [5]. Thus, management of safety relies on a systematic anticipation, monitoring and development of organizational performance. Various safety indicators play a key role in providing information on current organizational safety performance. An increasing emphasis has been placed also on the role of indicators in providing information to be used in anticipation and development of organizational performance. These indicators are called leading indicators.

The safety performance indicators that have commonly been used have often been lagging - measuring outcomes of activities or things and events that have already happened. In order to be able to monitor the effects of proactive safety work as well as anticipate vulnerabilities the organizations should define leading indicators. Those should be able to grasp organizational practices and processes that antecede (lead) changes in safety performance of the organization. Hollnagel [6] calls this kind of control feed-forward control. This kind of control relies on anticipated effects instead of past outcomes contrary to the traditional feedback-based safety management.

The categorization of safety performance indicators into lead and lag is dependent on the underlying model of safety. If one has a mechanistic 
and technical-oriented view on nuclear safety, near-misses can be considered leading indicators. More systemic and dynamic view of an organization and system safety would not view nearmisses as leading indicators, rather more as indicators of past safety performance. Another typical safety model emphasizes the latent failures (pathogens) of the sociotechnical system as creating conditions for accident [7].

Several reasons for using leading indicators have been proposed in the literature: they provide information on where to focus improvement efforts, they direct attention to proactive measures of safety management rather than reactive follow up of negative occurrences or trending of events, they provide early warning signs on potential weak areas or vulnerabilities in the organizational risk control system or technology, they focus on precursors to undesired events rather than the undesired events themselves, they provide information on the effectiveness of the safety efforts underway and they tell about the organizational health, not only sickness or absence of it.

Woods [8] reports that a resilient organization has the ability to create ways to anticipate the risk, before failures occur. The term Resilience Engineering represents a new way of thinking about safety. Whereas conventional risk management approaches are based on hindsight and emphasize error tabulation and calculation of failure probabilities. Resilience Engineering looks for ways to enhance the ability of organizations to create processes that are robust yet flexible, to monitor and revise risk models, and to use resources proactively in the face of disruptions or ongoing production and economic pressures.

According to Wreathall [9] the indicators are development and in way that can identify potential concerns in the plant's performance based on process that translates broad themes into specific plant issues. This author identified some themes or properties relevant to resilient organizations:

- Top-level commitment: Top management recognizes the human performance concerns and tries to address them, infusing the organization with a sense of significance of human performance, and is seen to value human performance, both in word and deed.

- Learning culture: A shorthand version of this theme is "How much does the organization respond to events with denial versus repair or true reform?"
- Flexibility: It is the ability of the organization to adapt to new or complex problems in a way that maximizes its ability to solve the problem without disrupting overall functionality. It requires that people at the working level are able to make important decisions without having to wait unnecessarily for management instructions.

- Just culture: Supports the reporting of issues up through the organization, yet not tolerating culpable behaviors. Without a just culture, the willingness of the workers to report problems will be much diminished, thereby limiting the ability of the organization to learn about weaknesses in its current defenses.

- Awareness: Data gathering that provides management with insights about what is going on regarding the quality of human performance at the plant, the extent to which it is a problem, and the current state of the defenses.

- Preparedness: "Being ahead" of the problems in human performance. The organization actively anticipates problems and prepares for them.

The true challenge has been to translate the themes into observable actions - leading indicators - that can be monitored [9].

This work presents a method based on a leading indicators framework that is relevant to assess safety and resilience of the radiopharmaceuticals production plant at Rio de Janeiro. This framework was based on the six major themes or properties relevant to resilient organizations (resilience engineering principles): top-level commitment, awareness, preparedness, flexibility, just culture and learning culture.

\section{Method to assess safety and resilience}

Selection of safety indicators should always start from the consideration of what are the key issues to monitor, manage and change. Only after these issues have been identified should one start to define safety management actions that seek to address the key issues as well as indicators to help the process. The safety indicators are utilized as part of the safety management process, not as an independent goal or function as such. The role of the safety performance indicators is to provide information on safety, motivate people to work on safety and contribute to change towards increased safety. 
When selecting the indicators it is important first to consider what needs to be monitored and not how these are monitored [10]. Otherwise the selection of indicators can be biased by relying on what is considered as possible or convenient to measure, and not on what information needs to be obtained about the safety level of the organization.
The leading indicators to the radiopharmaceuticals production process is presented in table 1 . The list is considered a pragmatic tool to guide attention to the relevant aspects, not a formal auditing check list. The main themes are based on Wreathall's study [9] and the specific contents of the themes include input from EPRI [10] and IAEA [11][12].

Table 1

Leading indicators framework

\begin{tabular}{|c|c|}
\hline Themes & Indicators \\
\hline \multirow[t]{7}{*}{ 1. Top-level commitment } & $\begin{array}{l}\text { 1.1 The availability of sufficient workforce is ensured in order to ensure that time pressure does not } \\
\text { compromise quality in safety-critical tasks. }\end{array}$ \\
\hline & $\begin{array}{l}\text { 1.2 The availability of sufficient material resources (tools, instruments) is appropriate and up-to- } \\
\text { date. }\end{array}$ \\
\hline & 1.3 Owners of the radiopharmaceuticals production process show a commitment to safety activities. \\
\hline & 1.4 Safety policy is defined, reviewed and updated regularly. \\
\hline & $\begin{array}{l}1.5 \text { The know-how of the workers is utilized in creating and revising of rules, instructions and util- } \\
\text { ized in setting safety goals. }\end{array}$ \\
\hline & $\begin{array}{l}\text { 1.6 There are clear objectives established for training programs; extent to which the personnel have } \\
\text { been trained in accordance with planned training programme. }\end{array}$ \\
\hline & $\begin{array}{l}1.7 \text { An adequate recruitment procedure exists for identifying competence needs and selecting suit- } \\
\text { able candidates. }\end{array}$ \\
\hline \multirow[t]{9}{*}{ 2. Learning culture } & $\begin{array}{l}2.1 \text { There is adequate information dissemination on safety issues and information that is relevant for } \\
\text { work is easily accessible. }\end{array}$ \\
\hline & 2.2 Information flow in change of shifts situations is assured. \\
\hline & 2.3 The extent to which work is carried out in accordance to the processes, procedures and rules. \\
\hline & $\begin{array}{l}2.4 \text { The extent to which tasks are performed faster and more efficient ways and these ways are re- } \\
\text { ported. }\end{array}$ \\
\hline & $\begin{array}{l}2.5 \text { The extent to which tasks are adapted to the circumstances on the field and the local adaptations } \\
\text { are based on understanding of their effects on safety. }\end{array}$ \\
\hline & 2.6 Procedures, instructions and documentation are appropriate and up to date. \\
\hline & 2.7 Procedures, instructions and documentation are available. \\
\hline & $\begin{array}{l}2.8 \text { There is a system for investigation and analysis of internal incidents that takes into account tech- } \\
\text { nical, human and organizational factors in equal degree. }\end{array}$ \\
\hline & 2.9 Incident and accident investigations are conducted by multidisciplinary teams. \\
\hline \multirow[t]{6}{*}{ 3. Flexibility } & $\begin{array}{l}\text { 3.1 Extent to which the personnel has been trained in technical areas and safety issues including } \\
\text { uncertainties and potential hazards of the radiopharmaceuticals production process to cope with } \\
\text { unexpected or demanding situations. }\end{array}$ \\
\hline & $\begin{array}{l}3.2 \text { Extent to which the personnel have suitable skills, knowledge and experience to carry out their } \\
\text { tasks safely and effectively. }\end{array}$ \\
\hline & 3.3 The hands-on experience and skills of workers are utilized by foremen and managers. \\
\hline & 3.4 Extent to which the procedures inform the limits of safe working and how to detect mistakes. \\
\hline & 3.5 The local adaptations of the tasks are communicated by people. \\
\hline & 3.6 The successful local adaptations are incorporated into the procedure. \\
\hline \multirow[t]{5}{*}{ 4. Awareness } & $\begin{array}{l}\text { 4.1 The extent to which there is an open atmosphere concerning reporting of errors, deviations and } \\
\text { problems encountered during the execution of tasks. }\end{array}$ \\
\hline & $\begin{array}{l}4.2 \text { The personnel are informed about the overall safety level and current challenges on a regular } \\
\text { basis. }\end{array}$ \\
\hline & 4.3 The extent to which the communication mechanisms are available. \\
\hline & 4.4 Work climate supports team work and knowledge sharing. \\
\hline & $\begin{array}{l}4.5 \text { tasks are allocated in a manner that promotes both work motivation including skill development } \\
\text { as well as the safe and efficient carrying out of the given task. }\end{array}$ \\
\hline
\end{tabular}




\begin{tabular}{|c|c|}
\hline \multicolumn{2}{|c|}{\begin{tabular}{l|l} 
& $\begin{array}{l}4.6 \text { The extent to which the relations between various personnel groups are based on trust and shared } \\
\text { safety norms. }\end{array}$
\end{tabular}} \\
\hline & 4.7 The extent to which the demands of the tasks are in line with the skills of the workers. \\
\hline & $\begin{array}{l}\text { 4.8 The extent of awareness of technical/physical condition of systems, structures, components and } \\
\text { limitations of procedures and instructions. }\end{array}$ \\
\hline & $\begin{array}{l}4.9 \text { There is a program of preventive maintenance in place and it is revised according to mainte- } \\
\text { nance. }\end{array}$ \\
\hline & 4.10 There are proactive measures at place to identify new risks. \\
\hline \multirow{5}{*}{ 5. Just culture } & 5.1 Reporting of deviations, worries and own mistakes is encouraged by the superior. \\
\hline & 5.2 Superior provides fair treatment of subordinates, understanding that errors are natural. \\
\hline & 5.3 There is a clear distinction between unavoidable errors and unacceptable actions. \\
\hline & 5.4 People suffer penalties, sanctions or reprisals when they make mistakes. \\
\hline & 5.5 Peer assessments are involved in determining the outcome of disciplinary investigations. \\
\hline \multirow[t]{6}{*}{ 6. Preparedness } & 6.1 The institution as an adequate on-site emergency preparedness plan. \\
\hline & $\begin{array}{l}6.2 \text { The extent to which tasks and situations where routines may develop and where they might have } \\
\text { consequences for safety are identified. }\end{array}$ \\
\hline & 6.3 Condition monitoring for safety equipment is utilized to target preventive maintenance. \\
\hline & $\begin{array}{l}\text { 6.4 There is an adequate system for alarming within the enterprise as well as for external alarming of } \\
\text { the people. }\end{array}$ \\
\hline & $\begin{array}{l}6.5 \text { There is a procedure for the identification of possible degradation mechanisms and monitoring } \\
\text { the condition of safety critical components. }\end{array}$ \\
\hline & 6.6 There is regular training on emergencies on-site. \\
\hline
\end{tabular}

\section{Conclusion}

This paper presents a proactive method that to provide a basis for action without waiting for events. In other words, the leading indicator framework provides a basis for identification potential problems in radiopharmaceuticals production process.

Safety and resilience performance indicators can be used to signal whether the system provides the capabilities for adaptation during the execution of work activities so that workers can handle the increased demand without sacrificing system safety. As the result, the organizations that use resilience indicators will be able to proactively evaluate and manage safety.

This new approach allows the discovery of resilience sources that allow workers to reach the success in error situations. The leading indicators can also be seen as tools for the authorities for implementation of a safety management model consistent with real-world scenarios.

Future plans include the development of a computational system, with a structure based on fuzzy logic. The fuzzy logic will be used to rank the indicators based on professional experience and knowledge of experts in the nuclear area.

\section{References}

[1] Carvalho, P. V. R., Gomes, J. O., Huber, G. J., Vidal, M. C. Normal people working in normal organizations with normal equipment: System safety and cognition in a mid-air collision. Applied Ergonomics 40, 325-340 (2009).

[2] Dekker, S. Ten Questions About Human Error A New View of Human Factors and System Safety. Lawrence Erlbaum Associates, Taylor \& Francis Group (2005).

[3] Hollnagel, E., Woods, D.D., Leveson, N. (2006). Resilience engineering. Concepts and precepts. Aldershot: Ashgate (2006).

[4] Reiman, T., Oedewald, P. Assessment of Complex Sociotechnical Systems - Theoretical issues concerning the use of organizational culture and organizational core task concepts. Safety Science 45, 745-768 (2007).

[5] Reiman, T., Oedewald, P. Evaluating safety critical organizations. Focus on the nuclear industry. Swedish Radiation Safety Authority, Research Report 12 (2009).

[6] Hollnagel, E. Safety management - looking back or looking forward. In: Hollnagel, E., Nemeth, C.P. and Dekker, S. Resilience Engineering Perspectives, Volume 1. Remaining sensitive to the possibility of failure. Aldershot: Ashgate (2008). 
[7] Reason, J. Managing the risks of organizational accidents. Aldershot: Ashgate (1997).

[8] Woods, D. Essential Characteristics of Resilience. In: Hollnagel, E., Woods, D. \& Leveson, N. Resilience Engineering: Concepts and Precepts. Aldershot: Ashgate, (2006).

[9] Wreathall, J. Properties of Resilient Organizations: An Initial View. In: Hollnagel, E.; Woods, D. \& Leveson, N. Resilience Engineering: Concepts and Precepts. Aldershot: Ashgate (2006).
[10] EPRI. Guidelines for trial use of leading indicators of human performance: the human performance assistance package. Palo Alto, CA: Electric Power Research Institute (EPRI) (2000).

[11] IAEA. Operational safety performance indicators for nuclear power plants. Vienna: International Atomic Energy Agency (IAEA) (2000).

[12] IAEA. SCART Guidelines. Reference report for IAEA Safety Culture Assessment Review Team (SCART). Vienna: International Atomic Energy Agency (IAEA) (2008). 